\title{
The Type III Effector AvrBs2 in Xanthomonas oryzae pv. oryzicola Suppresses Rice Immunity and Promotes Disease Development
}

\author{
Shuai Li, Yanping Wang, Shanzhi Wang, Anfei Fang, Jiyang Wang, Lijuan Liu, Kang Zhang, \\ Yuling Mao, and Wenxian Sun \\ Department of Plant Pathology, China Agricultural University, Beijing 100193, China; Key Laboratory of Plant Pathology, \\ Ministry of Agriculture, China Agricultural University, Beijing 100193, China
}

Submitted 14 October 2014. Accepted 4 February 2015.

\begin{abstract}
Xanthomonas oryzae pv. oryzicola, the causal agent of bacterial leaf streak, is one of the most important bacterial pathogens in rice. However, little is known about the functions of individual type III effectors in virulence and pathogenicity of $X$. oryzae $\mathrm{pv}$. oryzicola. Here, we examined the effect of the mutations of 23 putative nontranscription activator-like effector genes on $X$. oryzae pv. oryzicola virulence. The avrBs 2 knock-out mutant was significantly attenuated in virulence to rice. In contrast, the $x o p A A$ deletion caused enhanced virulence to a certain rice cultivar. It was also demonstrated that six putative effectors, including ХopN, ХopX, ХорA, ХоpY, XopF1, and AvrBs2, caused the hypersensitive response on nonhost Nicotiana benthamiana leaves. Virulence function of AvrBs2 was further confirmed by transgenic technology. Pathogen-associated molecular pattern-triggered immune responses including the generation of reactive oxygen species and expression of pathogenesis-related genes were strongly suppressed in the AvrBs2-expressing transgenic rice lines. Although not inhibiting flg22-induced activation of mitogen-activated protein kinases, heterologous expression of AvrBs2 greatly promotes disease progression in rice caused by two important bacterial pathogens $X$. oryzae pvs. oryzae and oryzicola. Collectively, these results indicate that AvrBs2 is an essential virulence factor that contributes to $X$. oryzae pv. oryzicola virulence through inhibiting defense responses and promoting bacterial multiplication in monocot rice.
\end{abstract}

Plants possess multiple layers of preformed and induced defenses to protect themselves from pathogen attack (Jones and Dangl 2006). During plant-pathogen coevolution, pattern recognition receptors (PRR) in plants recognize pathogenassociated molecular patterns (PAMPs) such as bacterial flagellin and fungal chitin and, thus, trigger the first layer of defense responses, called PAMP-triggered immunity (PTI). PTI includes a series of defense signal transduction cascades that lead to callose deposition, bursts of reactive oxygen species (ROS), induced expression of pathogenesis-related $(P R)$ genes, phytoalexin accumulation, and the deposition of phenolic

Corresponding author: W. Sun; Telephone: +86 106273 3532; Fax: +86 10 6273 3532; E-mail: wxs@cau.edu.cn

*The $\boldsymbol{e}$-Xtra logo stands for "electronic extra" and indicates that eight supplementary figures and three supplementary tables are published online.

(C) 2015 The American Phytopathological Society compounds (Chisholm et al. 2006; Jones and Dangl 2006). Many gram-negative phytopathogenic bacteria, such as Pseudomonas and Xanthomonas spp., translocate a large number of type III effectors (T3E) into the host cells through the type III secretion system (Kay and Bonas 2009). The secreted T3E often target essential components in the PTI signaling pathway, such as PRR, mitogen-activated protein kinases (MAPK), and transcription factors to interfere with or suppress the plant immune system (Boller and He 2009; Dou and Zhou 2012; Xin and He 2013). Accordingly, plants have evolved to specifically recognize certain $\mathrm{T} 3 \mathrm{E}$ by the intracellular cognate resistance $(\mathrm{R})$ proteins to initiate the second layer of defenses, referred to as effector-triggered immunity (ETI). As compared with PTI, ETI is more robust and effective and is often characteristic of the hypersensitive response (HR) at the invasion site that inhibits pathogen multiplication (Chisholm et al. 2006; Jones and Dangl 2006).

As a major group of virulence factors, the T3E and their secretion apparatus encoded by the hypersensitive reaction and pathogenicity $(h r p)$ gene cluster are essential for pathogenesis and virulence of phytopathogenic bacteria (Alfano and Collmer 2004; Kay and Bonas 2009). In Xanthomonas spp., HrpX is a key hrp regulatory factor and regulates expression of some T3E genes through binding to the PIP (plant-inducible promoter) boxes (Furutani et al. 2006; Li et al. 2011). The PIP box is a conserved cis element consisting of the consensus sequence TTCGB-N15TTCGB ('B' represents any base except adenine) that is located at 30 to 32 bases upstream of the start codon of the effector gene (Furutani et al. 2006; Koebnik et al. 2006; Tsuge et al. 2006). The T3E usually carry a secretion signal at their N-terminus, which often contains 50 specific amino-acid residues (Alfano and Collmer 2004; Cunnac et al. 2004; Tampakaki et al. 2004).

The T3E in xanthomonads, also called Xanthomonas outer proteins (Xops), are categorized into up to 39 protein families based on sequence similarity, reflecting genetic diversity of the virulence factor inventory in the pathogens (White et al. 2009). A group of T3E unique to Xanthomonas spp. are called transcription activator-like (TAL) effectors (Scholze and Boch 2011) and others are grouped into non-TAL effectors (Furutani et al. 2009; White et al. 2009). Various biological functions of T3E in phytopathogenic bacteria, especially in Pseudomonas spp., have been recently revealed in succession (Xin and $\mathrm{He} 2013$ ). Some effectors, such as AvrPtoB, function as E3 ubiquitin ligases and promote the degradation of immunity-related proteins in a proteasome-dependent manner (Rosebrock et al. 2007). Some effectors, such as the YopJ/AvrRxv family, target the proteasomal subunit to inhibit the proteasome activity (Üstün et al. 2013). Some effectors, such as HopAO1, alter the phosphorylation state 
of host proteins ( $\mathrm{Li}$ et al. 2013; Underwood et al. 2007). Other effectors, especially for TAL effectors including the AvrBs3/PthA family, act as transcription factors that regulate expression of susceptibility genes in hosts and promote bacterial spreading and multiplication (Boch and Bonas 2010; Pereira et al. 2014).

In recent years, intensive research has been performed to study functions of the Xop proteins. Besides TAL effectors, some nonTAL effector genes, including $x o p R, x o p N$ and $x o p Z$, have been demonstrated to be required for full virulence in $X$. oryzae pv. oryzae (Akimoto-Tomiyama et al. 2012; Sinha et al. 2013; Song and Yang 2010). The X. campestris pv. vesicatoria effector XopX contributes to $X$. campestris pv. vesicatoria virulence in host pepper and tomato plants (Metz et al. 2005). Several host targets of the Xops have been identified recently. XopAA and XopY in $X$. oryzae pv. oryzae interact with OsSERK1/2 and OsRLCK185 to inhibit rice immunity, respectively (Yamaguchi et al. 2013a and b). The XopN homologs target a zinc finger domaincontaining protein, OsVOZ2, and a putative thiamine synthase, OsXNP, in rice (Cheong et al. 2013) and the atypical receptor-like kinase TARLK1 in tomato to promote pathogenicity (Kim et al. 2009). In X. campestris pv. vesicatoria, XopD functions as a SUMO protease and interacts with the transcription factor SIERF4, to inhibit ethylene production and to promote pathogen growth in tomato (Kim et al. 2008, 2013). It has recently been shown that XopQ in $X$. campestris pv. vesicatoria suppresses ETI by targeting the tomato 14-3-3 isoform SITFT4, an important component of ETI (Teper et al. 2014). The effector AvrAC secreted by $X$. campestris pv. campestris functions as a uridylyl transferase that transfers uridine $5^{\prime}$-monophosphate to and masks conserved phosphorylation sites in the activation loop of BIK1 and RIPK, thus preventing activation of these kinases and suppressing defense signaling in host (Feng et al. 2012). Most recently, XopD in X. campestris pv. campestris has been demonstrated to target DELLA proteins in Arabidopsis to trigger disease tolerance and increase bacterial survival (Tan et al. 2014).

Bacterial leaf streak (BLS), caused by X. oryzae pv. oryzicola, is currently one of the most serious bacterial diseases in rice and causes significant yield loss in rice-growing regions of South Asia and South China (Niño-Liu et al. 2006). Due to similar biochemical characteristics and disease symptoms on rice leaves, the disease was previously considered to be bacterial blight. Subsequent studies revealed significant differences in infection style and pathogenicity between $X$. oryzae pvs. oryzae and oryzicola (Bogdanove et al. 2011; Vauterin et al. 1995). X. oryzae pv. oryzicola enters and colonizes the intercellular spaces between mesophyll cells in rice leaves through stomata or wounds. In contrast, $X$. oryzae pv. oryzae infects rice leaves through vascular tissues and causes a systemic disease (Niño-Liu et al. 2006). Therefore, molecular mechanisms underlying virulence and pathogenicity might be significantly different between $X$. oryzae pvs. oryzae and oryzicola. The inventories of effector proteins in many Xanthomonas species have been predicted from publicly available genome sequences of these species (The Xanthomonas Resource database) (Bogdanove et al. 2011). As mentioned above, functional studies on Xops focus on only a few Xanthomonas species, including $X$. oryzae pv. oryzae and $X$. campestris pvs. campestris, and vesicatoria. As compared with ever-increasing reports on $X$. oryzae pv. oryzae effectors, little is known about the functions of $X$. oryzae pv. oryzicola effector proteins, particularly for non-TAL effectors.

AvrBs2, the first reported non-TAL effector in X. campestris pv. vesicatoria (Kearney and Staskawicz 1990), is highly conserved in xanthomonads (Swords et al. 1996). AvrBs2 was characterized as an avirulence protein that is recognized by the $\mathrm{R}$ protein Bs2 in pepper (Gassmann et al. 2000; Tai et al. 1999). Computational and biochemical evidence showed that AvrBs2 contains a glycerophosphodiesterase catalytic domain that is essential for its virulence function but not for activation of Bs2mediated disease resistance (Zhao et al. 2011). Functional studies on AvrBs2 have been focused on the dicot plants. In contrast, no experiment has been performed so far to determine whether $a v r B s 2$ in $X$. oryzae pv. oryzicola is required for bacterial virulence to the monocot rice.

In this study, we performed mutational analyses of 23 putative Xop genes in the $X$. oryzae pv. oryzicola RS105, revealing that the effector gene $a v r B s 2$ is required for full virulence of $X$. oryzae pv. oryzicola. It was also demonstrated that multiple effectors including XopN, XopA, XopX, XopF1, XopY, and AvrBs2 triggered HR in nonhost $N$. benthamiana to different degrees. Ectopic expression of AvrBs2 in transgenic rice plants inhibited defense responses including flg22- and chitin-triggered ROS burst and $P R$ gene expression and, importantly, promoted disease progression after infection by rice bacterial pathogens.

\section{RESULTS}

\section{Construction of gene-deletion mutants for 23 putative non-TAL effector genes in $X$. oryzae pv. oryzicola.}

The effector genes in $X$. oryzae pv. oryzicola have been predicted based on the available genome sequence of $X$. oryzae pv. oryzicola BLS256 (Bogdanove et al. 2011). Among them, at least 26 genes were predicted to encode non-TAL effectors. The degree of conservation of these effectors was predicted and compared among Xanthomonas species (Supplementary Fig. S1), and the location of these genes in the genome and the sequences of the PIP boxes were also identified (Supplementary Table S1). The majority of non-TAL effectors are highly conserved, although some effector genes have presence/absence polymorphisms in Xanthomonas species (Bogdanove et al. 2011). A total of 11 non-TAL effector families are widely distributed in genome sequence-available Xanthomonas species and, thus, are considered as core effector proteins in xanthomonads. A few effector genes including $x о p U, x о p W, x о p Y$, and $x о р A B$ are present exclusively in Xanthomonas oryzae pathvars. The xopT and xopAF genes only exist in $X$. oryzae pvs. oryzae and oryzicola, respectively. The xopO and xopAJ genes exist in both $X$. oryzae pvs. oryzicola and vesicatoria. Among the 26 non-TAL effectors, the only XopAF is unique to $X$. oryzae pv. oryzicola.

To initially understand the roles of putative non-TAL effector genes in X. oryzae pv. oryzicola virulence, marker-free deletion mutants of the 23 effector genes were constructed via homologous recombination as described below. The xopA and $h p a A$ were excluded in mutational analyses, since they most likely encode a harpin and a type III system control protein, respectively, which might not be T3E, and xopAJ, also called avrRxol, was not selected because of failure to make the avrRxol knock-out mutant in a previous study (Zhao et al. 2004). The mutant strains were used for subsequent functional studies after being confirmed through Southern blot analyses (Supplementary Figs. S2 and S3).

\section{The mutations of $a v r B s 2$ and $x o p A A$ cause altered virulence of $X$. oryzae pv. oryzicola to rice.}

To determine whether the putative effector genes are required for full virulence of $X$. oryzae pv. oryzicola to rice, all constructed marker-free gene-deletion mutants were pressure-inoculated into rice leaves for virulence assays. Virulence of each mutant strain was evaluated by the measured length of disease lesions at 2 weeks after inoculation compared with that of the wild-type strain. The results demonstrated that all gene-deletion mutants except $\triangle a v r B s 2$ and $\triangle x o p A A$ exhibited no or little alteration in $X$. oryzae pv. oryzicola virulence under the experimental conditions used in this study (Fig. 1A). Disease lesions in the $\Delta a v r B s 2$-inoculated leaves were much shorter than those caused 
by the wild-type strain (Fig. 1A; Supplementary Fig. S4). The complementation strain with the plasmid-borne full-length $a v r B s 2$ gene largely restored virulence of the $\Delta a v r B s 2$ mutant toward the wild-type level. Enumeration of bacteria extracted from inoculated rice leaves clearly showed that the in planta population size of $\triangle a v r B s 2$ was much smaller than that of the wild-type and complementation strains during infection (Fig. 1B). Taken together, the data indicate that AvrBs2 is one of the major virulence factors and plays an essential role in virulence and multiplication of $X$. oryzae pv. oryzicola in rice. Interestingly, the $\triangle x o p A A$ mutant caused significantly longer disease lesions on the leaves of rice cv. Jingang 30 than the wild-type strain (Fig. 1A). The population size of $\triangle x o p A A$ was also larger than that of the wild-type strain in inoculated rice leaves 8 days after inoculation (Fig. 1C). Introduction of the plasmid-borne $x o p A A$ gene reduced virulence of the $\triangle x о p A A$ mutant to the wild-type level (Fig. 1A and $C$ ). Virulence of the $x o p A A$ mutant to rice was further tested using the other two rice cultivars, Nipponbare and Jinhe 2. The results showed that the xорAA mutant and wild-type strains caused almost equal length of disease lesions on these cultivars (Supplementary Fig. S5). The data suggest that XopAA in $X$. oryzae pv. oryzicola triggers defense responses in a certain rice genetic background.

\section{The HR triggered by putative $X$. oryzae pv. oryzicola} effectors on nonhost $\boldsymbol{N}$. benthamiana leaves.

$X$. oryzae pv. oryzicola causes nonhost hypersensitive cell death in $N$. benthamiana. In order to investigate which effector candidates have cell death-eliciting activities in $N$. benthamiana, 22 putative effectors, not including XopAB, XopZ1, XopAA, and $\mathrm{XopO}$, were transiently expressed in $N$. benthamina by Agrobacterium tumefaciens-mediated expression system. The cell-death symptoms were monitored within 3 days after treatment with dexamethasone (DEX), which induced expression of these effector genes. The infiltrated leaf area expressing XopN became necrotic at 1 day after DEX treatment. Expression of

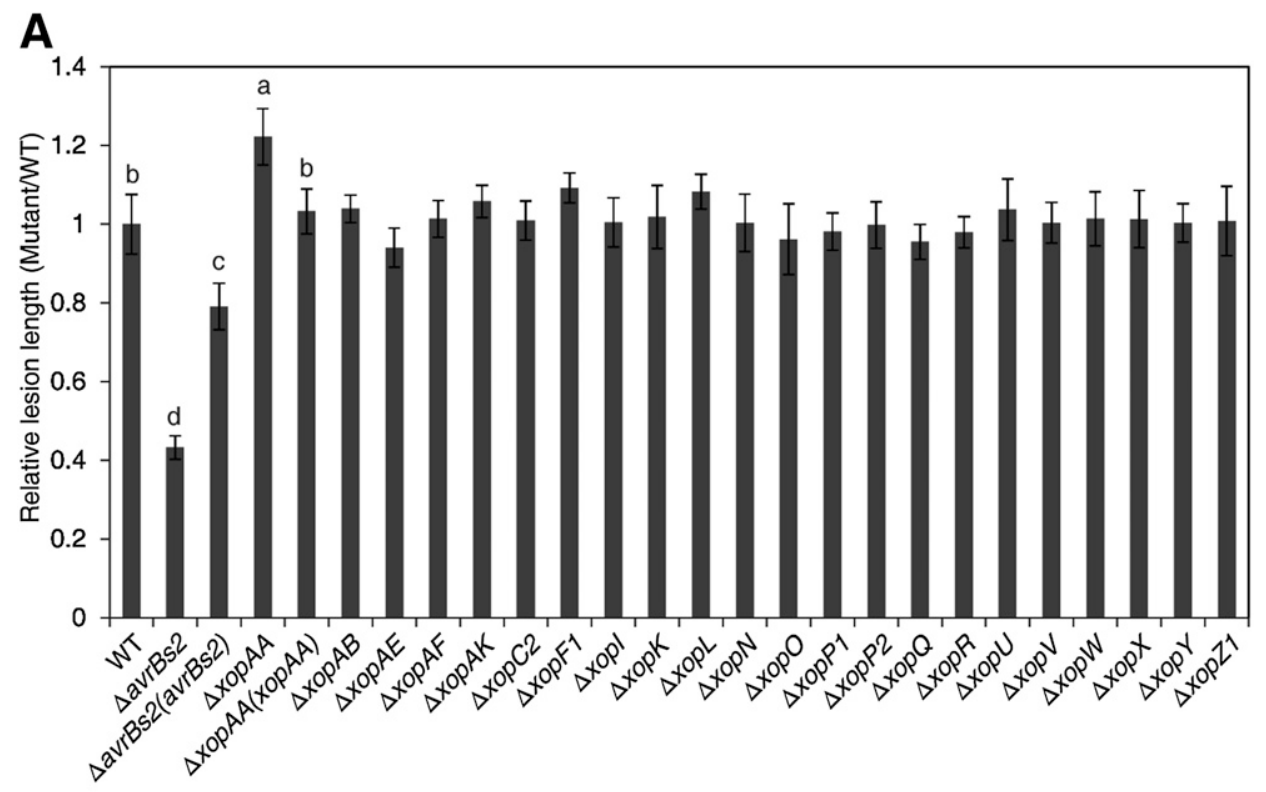

B
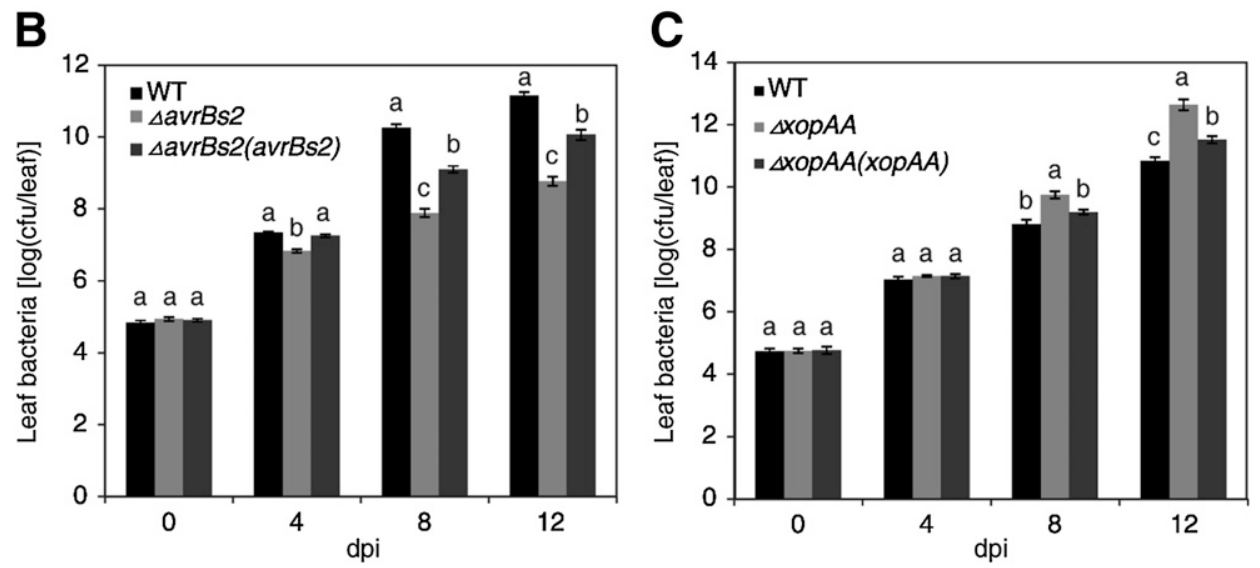

Fig. 1. The effects of mutation of each putative effector gene on virulence of Xanthomonas oryzae pv. oryzicola to rice. A, Mutation of avrBs 2 caused a significant reduction in virulence, while the $\triangle x o p A A$ mutant exhibited an enhanced virulence on rice cv. Jingang 30 in repeatable tests. Virulence of the $\Delta a v r B s 2$ and $\triangle x o p A A$ mutants was successfully complemented with plasmid-borne full-length $a v r B s 2$ and $x o p A A$ genes, respectively. Virulence of each mutant was evaluated by the length of disease lesions after bacteria were inoculated into rice leaves by pressure infiltration compared with that caused by the wild-type (WT) strain. The length of disease lesions was measured at 14 days after inoculation for 10 to 15 leaves per strain. The gene-deletion mutants were constructed for 23 of 26 putative effector genes that were all present in the $X$. oryzae pv. oryzicola RS105 strain. B, In planta bacterial population of $X$. oryzae pv. oryzicola $\mathrm{RS} 105, \Delta a v r B s 2$, and $\Delta a v r B s 2(a v r B s 2)$ at the indicated days postinoculation (dpi). C, In planta bacterial population of $X$. oryzae pv. oryzicola RS105, $\Delta x o p A A$, and $\triangle x о р A A(x о р A A)$ at the indicated time points after inoculation. Bars are means \pm standard error. Different letters a to d indicate statistically significant difference $(P<0.05) . \Delta a v r B s 2(a v r B s 2)$ and $\triangle x o p A A(x o p A A)$ are the complementation strains of $\triangle a v r B s 2$ and $\Delta x o p A A$, respectively. 
XopX and XopA caused similar HR symptoms at approximatey 2 days, while XopF1, XopY, and AvrBs2 induced cell-death phenotypes at approximately 3 days. XopN and XopX caused HR on all of 20 inoculated leaves, while XopA, XopY, XopF1, and AvrBs2 induced HR to relatively lower degrees (Fig. 2A). Other tested putative effectors did not trigger cell-death symptoms in $N$. benthamiana, although expression of those proteins was all confirmed by Western blotting (Fig. 2B).

\section{Flg22-induced immunity is suppressed by transient} expression of AvrBs2 in Arabidopsis protoplasts.

The expression of NONHOST1 (NHO1), an essential gene for nonhost resistance, is induced by flg22 in Arabidopsis. It has been well demonstrated that flg22-induced $\mathrm{NHO1}$ expression was inhibited by different T3E in Arabidopsis protoplasts (Li et al. 2005; Lu et al. 2001). Transient expression assays in Arabidopsis protoplasts were used herein to investigate if AvrBs2 can suppress flg22-induced $\mathrm{NHO1}$ expression. Protoplasts isolated from the $\mathrm{NHO1-luciferase} \mathrm{(NHO1-LUC)}$ transgenic Arabidopsis plants were transfected with an empty vector and the hopAII construct as negative and positive controls,
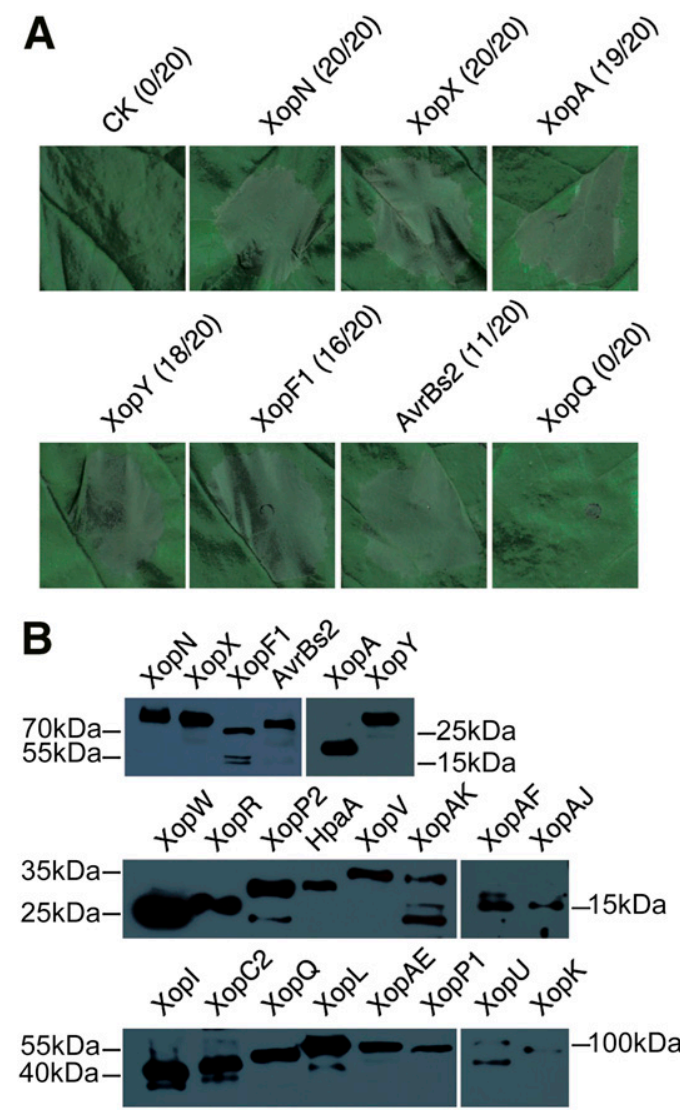

Fig. 2. Cell death symptoms on Nicotiana benthamiana leaves caused by transient expression of Xanthomonas oryzae pv. oryzicola putative effectors. A, Six proteins of the 22 tested putative effectors, i.e., XopN, XopX, XopA, XopY, XopF1, and AvrBs2, caused the hypersensitive response in $N$. benthamiana to different degrees. XopQ, which did not induce HR, was shown as a negative control. Agrobacterium cultures transformed with different effector constructs were infiltrated into $N$. benthamiana leaves, followed by dexamethasone (DEX) spraying. Representative photos were taken at 3 days after DEX treatment. Numbers in parentheses, e.g., 18/20, indicate that 18 of 20 inoculated leaves exhibited cell-death symptoms. CK, empty vector. B, Transient expression of 22 tested putative effectors in $N$. benthamiana was confirmed via Western blot analyses. The samples for protein extraction were collected before cell-death symptoms were visible. The effectors with the FLAG tag were detected by immunoblotting with an anti-FLAG antibody. respectively. As shown in Figure 3A, LUC expression driven by the $\mathrm{NHO1}$ promoter was greatly induced by flg22 in protoplasts transfected with empty vector. Transfection of the avrBs 2 construct nearly abolished flg22-induced LUC expression, which was similar to transfection of hopAI1. These data suggest that transient expression of AvrBs2 in protoplasts strongly suppresses flg22-induced expression of defense genes.

In order to determine subcellular localization of AvrBs2 in host cells, the green fluorescent protein $(G F P)$ gene was fused in frame with the $a v r B s 2$ coding sequence at its $\mathrm{C}$ terminus in the pUC19 plasmid with the $35 \mathrm{~S}$ promoter. The recombinant AvrBs2-GFP protein was transiently expressed in rice protoplasts. Green fluorescence of AvrBs2-GFP was detected across the entire cell, which is similar to subcellular localization of AvrBs2-GFP in N. benthamiana (Fig. 3B; Supplementary Fig. S6). Transient expression of AvrBs2-GFP in N. benthamiana caused HR symptoms, indicating that the AvrBs2-GFP fusion protein is functional (data not shown).

\section{Ectopic expression of AvrBs2 suppresses PTI signaling in rice cell cultures.}

To investigate if AvrBs2 suppresses plant immunity in rice, the transgenic rice cell cultures with heterologous expression of AvrBs2-FLAG driven by the DEX-inducible promoter was generated in the genetic background of rice cv. Nipponbare. Induced expression of avrBs2-FLAG in the transgenic rice cells was confirmed by quantitative real time reverse transcriptionpolymerase chain reaction (RT-PCR) (data not shown) and

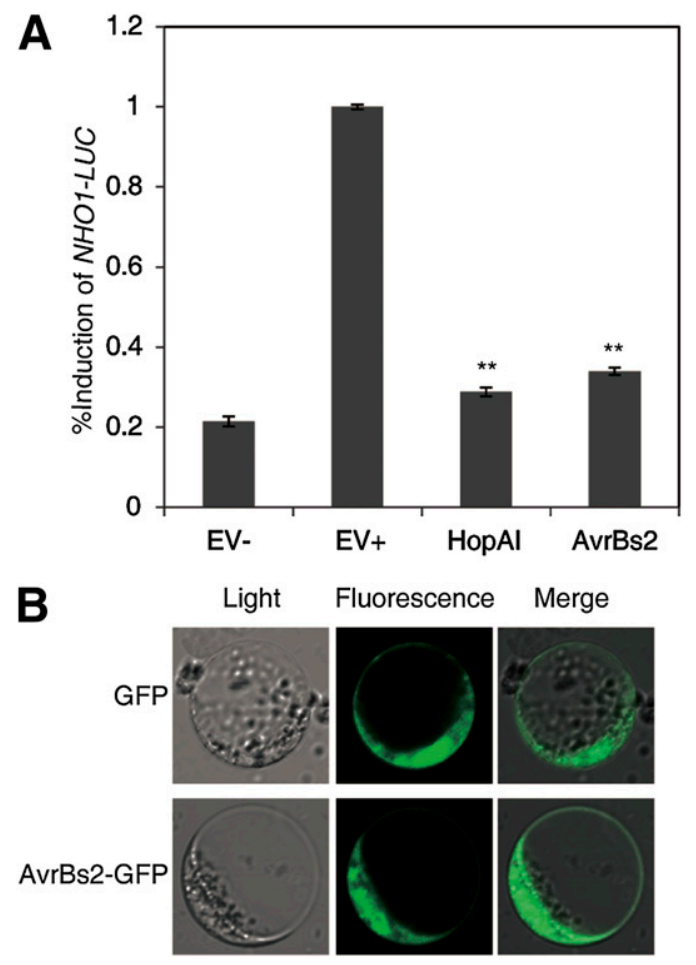

Fig. 3. Transient expression of AvrBs2 inhibits flg22-induced NHO1-LUC expression in Arabidopsis protoplasts. A, The relative luciferase (LUC) activity in transfected Arabidopsis protoplasts. Protoplasts were transfected either with the $a v r B s 2$ gene construct or empty vector (EV). The relative LUC activity was measured $12 \mathrm{~h}$ after flg 22 treatment. EV- indicates EVtransfected protoplasts treated with distilled $\mathrm{H}_{2} \mathrm{O}$, which was used as a control for basal NHO1-LUC expression. EV+ represents EV-transfected protoplasts treated with $1 \mu \mathrm{M}$ flg22. Each data point (mean \pm standard error) consists of ten replicates. The experiments were repeated at least three times with similar results. Asterisks $(* *)$ indicates $P$ value $<0.01$. B, Subcellular localization of AvrBs2-GFP transiently expressed in rice protoplasts. The empty vector pUC19-35S-GFP was used as a control. 
immunoblotting (Fig. 4A). As virulence factors, the effectors secreted by plant pathogens often suppress defense responses including PAMP-triggered ROS burst, $P R$ gene expression, and MAPK activation (Boller and He 2009; Dou and Zhou 2012). Previous studies revealed that rice senses the PAMPs flg22 and chitin through OsFLS2 (Takai et al. 2008) and through synergetic action of CEBiP and CERK1 (Shimizu et al. 2010), respectively. Here, we measured ROS accumulation in the avrBs 2 transgenic rice cell cultures after DEX treatment followed by flg22 and chitin stimulation, using a highly sensitive ROS detection method. ROS bursts were clearly detected in the transgenic cell cultures with mock treatment in response to flg22 and chitin (Fig. 4B and C). In contrast, ROS accumulation induced by flg22 was reduced up to approximately $60 \%$ and chitin-induced ROS was inhibited even more dramatically in the avrBs 2 transgenic cell cultures after DEX treatment (Fig. 4B and C). Furthermore, the defense marker genes $O s P B Z 1$ and $O s P A L 1$ were demonstrated to be upregulated by flg22 and chitin in the transgenic rice cell cultures with mock treatment. Remarkably, induced expression of the two defense genes was almost completely blocked in the transgenic rice cells after DEX-induced expression of AvrBs2 (Fig. 4D and
E). These data indicate that AvrBs 2 contributes to $X$. oryzae pv. oryzicola virulence by suppressing PAMP-triggered defense responses in rice.

\section{Ectopic expression of AvrBs2 suppresses PTI signaling and promotes disease progression in rice plants.}

To further confirm virulence functions of $X$. oryzae pv. oryzicola AvrBs2 in suppressing rice immunity, stably transformed transgenic rice plants with DEX-inducible expression of AvrBs2FLAG were created. Among eight independent transgenic lines, the two T2 homozygous lines A4 and A5 were selected for subsequent functional studies. The transgenic A5 line with a low leaked expression had a lower expression level of AvrBs 2 than the A4 line after DEX treatment (Fig. 5A). Consistent with the results in transgenic cell cultures, we showed that flg22 and chitin induced expression of $O s P B Z 1$ and $O s P A L 1$ in the mock-treated transgenic plant leaves and the induction was dramatically suppressed by DEX-induced expression of AvrBs2 (Fig. 5B and C). In contrast, MAPK activation induced by flg22 or chitin was not significantly altered by AvrBs2 expressed in the transgenic plants after DEX treatment (Supplementary Fig. S7).
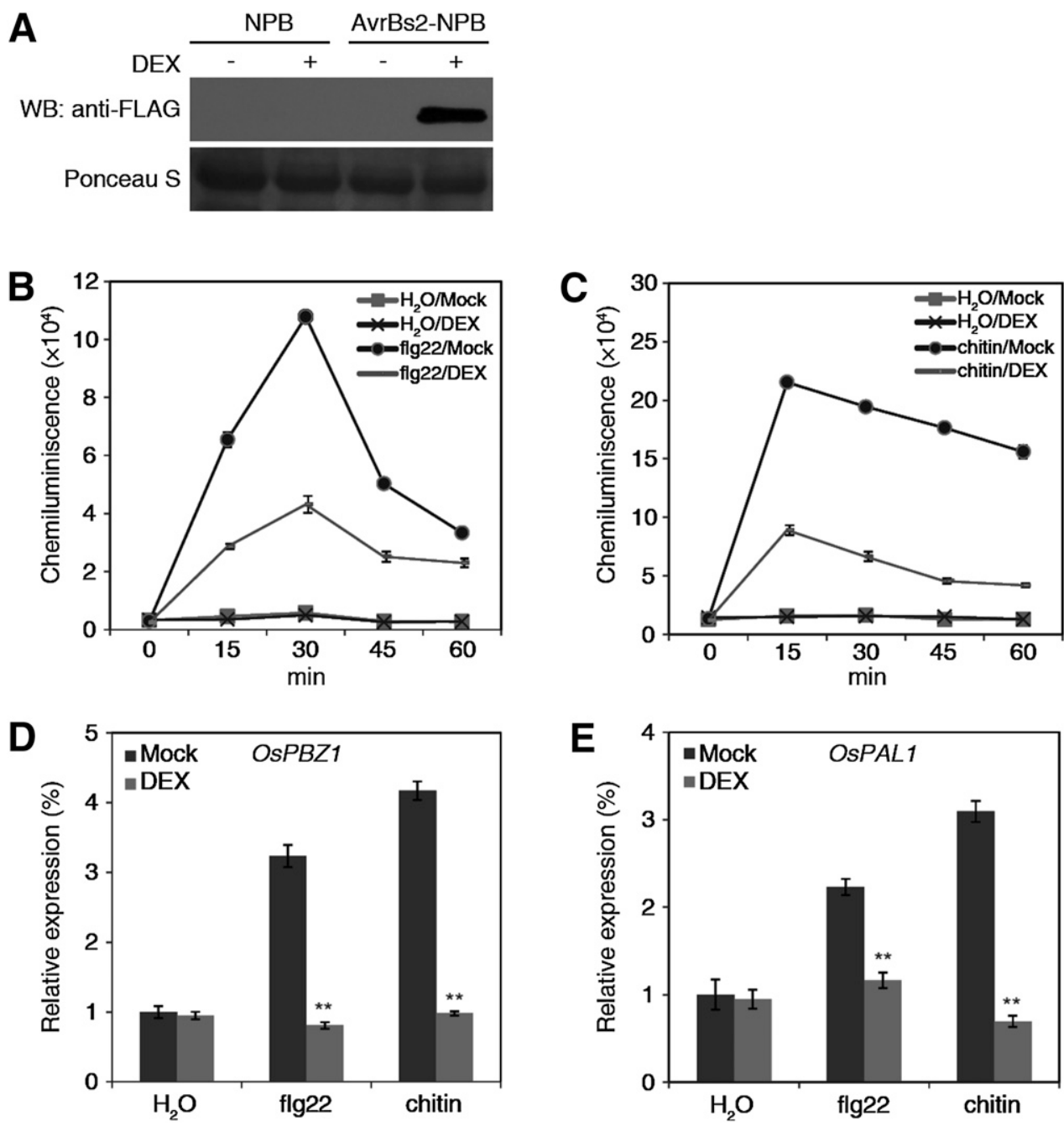

Fig. 4. Heterologous expression of AvrBs2 inhibits pathogen-associated molecular pattern-induced reactive oxygen species (ROS) burst and defense gene expression in transgenic rice culture. A, Expression of AvrBs2 in transgenic rice cell culture induced by dexamethasone (DEX) treatment. The AvrBs2-FLAG fusion was detected by Western blotting with an anti-FLAG antibody. NPB $=$ Nipponbare; $-=$ without DEX treatment; $+=$ with DEX treatment; $\mathrm{WB}=$ Western blot. Ponceau S staining shows the equal loading of the total proteins. B and C, ROS burst induced by flg22 and chitin, respectively, was significantly suppressed in the avrBs 2 transgenic cell culture after DEX treatment. ROS generation was detected by a luminol-chemiluminescence assay. D and E, Upregulation of the defense marker genes $O s P B Z 1$ and $O s P A L 1$, respectively, induced by flg22 and chitin was almost completely blocked in the avrBs2 transgenic cell culture after DEX treatment. The transgenic cell culture was treated with $10 \mu \mathrm{M}$ DEX or $0.03 \%$ ethanol as mock control for $24 \mathrm{~h}$, followed by the treatment of $1 \mu \mathrm{M}$ flg22 or chitin. Astericks (**) indicate $P$ value $<0.01$; means \pm standard error are shown. 
It is important to investigate whether AvrBs2 expression in the transgenic plants promotes disease development during the infection of bacterial pathogens. Bacterial disease susceptibility in the $a v r B s 2$ transgenic plants was first evaluated after $X$. oryzae pv. oryzicola inoculation. Disease symptoms observed on the inoculated leaves showed that disease lesions in transgenic rice lines A4 and A5 were significantly longer after DEX spraying, as compared with those under mock treatment. The lesion length on the A4 transgenic line was longer than that on the A5 line, which is consistent with the higher AvrBs2 expression level in the A4 line after DEX induction (Fig. 5A and D; Supplementary Fig. S8).
Bacterial growth curve assays demonstrated that the population size of $X$. oryzae pv. oryzicola in the transgenic lines upon DEX treatment was also significantly higher than that in the wild-type plant at 12 days after pathogen inoculation (Fig. 5E). Meanwhile, these transgenic plants, when treated with DEX, also exhibited more severe disease symptoms with longer disease lesions than the wild-type plants after $X$. oryzae pv. oryzae inoculation (Fig. $5 F)$. Collectively, these results indicate that AvrBs2 expression in the transgenic rice plants disrupts plant basal defenses during the compatible interaction and, thus, promotes bacterial multiplication and disease symptom development.

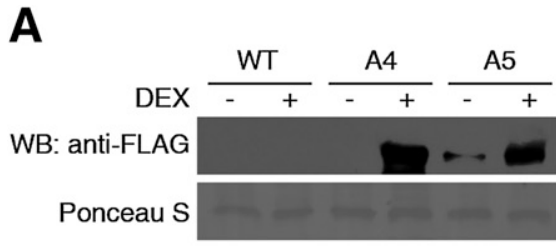

B
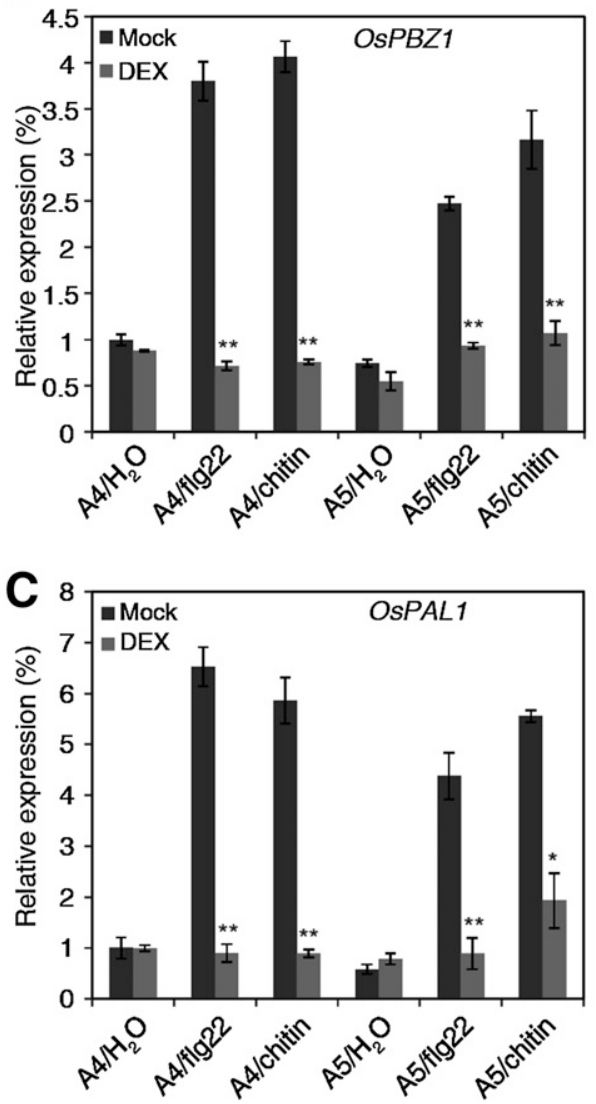

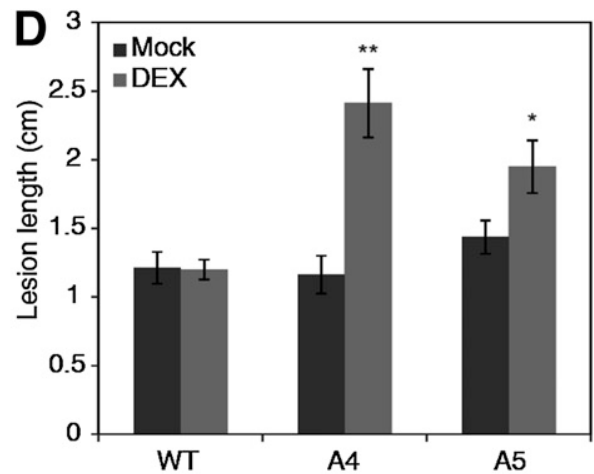

E
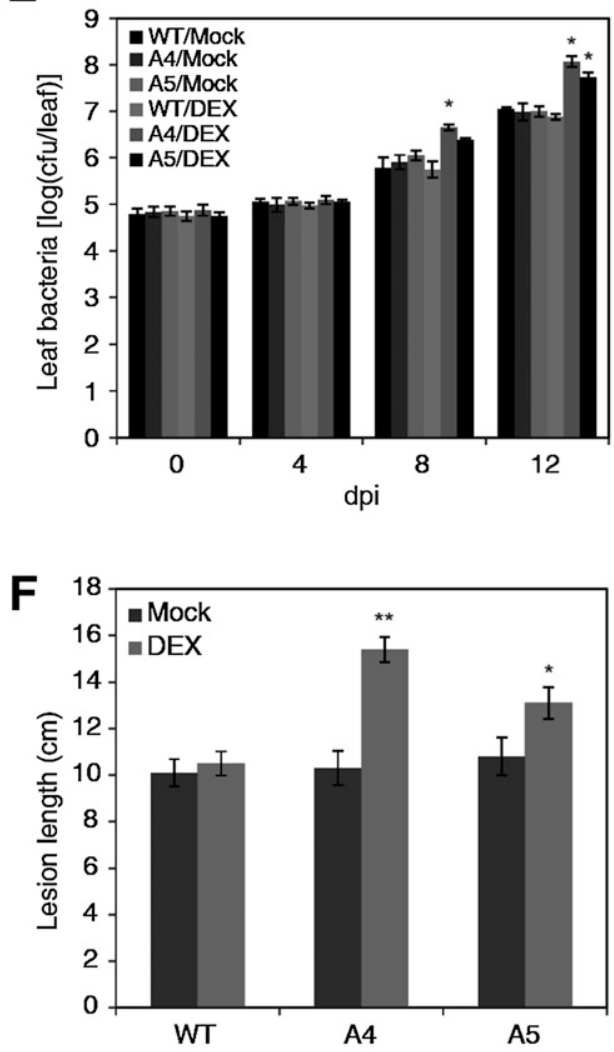

Fig. 5. Heterologous expression of AvrBs2 suppresses rice immunity and promotes disease progression caused by bacterial pathogens in transgenic rice plants. A, Induced expression of AvrBs2 in the T2 transgenic homozygous lines A4 and A5 after dexamethasone (DEX) treatment. The AvrBs2-FLAG fusion was detected by Western blotting with an anti-FLAG antibody. WT $=$ the wild-type rice; $-=$ without DEX treatment; + = with DEX treatment; WB $=$ Western blot. Ponceau S staining shows the equal loading of the total proteins. B and C, Upregulation of the defense marker genes $O s P B Z 1$ and $O s P A L 1$, respectively, induced by flg22 and chitin was almost completely inhibited in the $a v r B s 2$ transgenic A4 and A5 lines upon DEX treatment. The rice leaves were sprayed with $30 \mu \mathrm{M}$ DEX or $0.1 \%$ ethanol as mock control, followed by incubation with flg 22 or chitin for $6 \mathrm{~h}$. D, The length of disease lesions caused by the Xanthomonas oryzae pv. oryzicola RS105 in the wild-type Nipponbare and $a v r B s 2$ transgenic lines A4 and A5. E, In planta bacterial population of RS105 in the wild type and avrBs2 transgenic lines A4 and A5 at the indicated time points after inoculation. F, The length of disease lesions caused by X. oryzae pv. oryzae PXO99A in the wild type and avrBs 2 transgenic lines A4 and A5. The wild-type and avrBs 2 transgenic lines were inoculated with X. oryzae pv. oryzicola and X. oryzae pv. oryzae at $24 \mathrm{~h}$ after spraying with $30 \mu \mathrm{M}$ DEX and $0.1 \%$ ethanol as mock control. Asterisks ( $*$ and $* *$ ) indicate $P$ values $<0.05$ and 0.01 , respectively; means \pm standard error are shown. 


\section{DISCUSSION}

Rice, one of the staple food crops, is subject to infection of various pathogenic microbes. $X$. oryzae pv. oryzicola causes BLS, which is currently one of the most serious bacterial diseases in rice and is a great threat to commercial production (Xue et al. 2014). Breeding for disease resistance in rice is considered to be the most effective, environmentally friendly approach to controlling the disease. However, no endogenous BLS resistance gene has been identified in rice so far, although a bunch of resistance genes are available for bacterial blight (Niño-Liu et al. 2006). The lack of BLS-resistant germplasm in rice might be partially explained by the finding that $R$ genemediated resistance is suppressed by the T3E secreted by $X$. oryzae pv. oryzicola (Makino et al. 2006). Therefore, it is important to study the effect of individual effectors on $X$. oryzae pv. oryzicola virulence for better understanding of molecular mechanisms underlying virulence and pathogenicity of $X$. oryzae pv. oryzicola. In this study, we investigated the contribution of each non-TAL effector gene to $X$. oryzae pv. oryzicola virulence in a genome-wide analysis. Among 23 tested genedeletion mutants of the $X$. oryzae pv. oryzicola RS105 strain, the $a v r B s 2$ mutation is the only one that leads to reduced virulence of $X$. oryzae pv. oryzicola to rice, while the deletion of xopAA enhanced $X$. oryzae pv. oryzicola virulence exclusively to rice cv. Jingang 30 . It is notable that the mutational study did not include the previously identified effector genes $h r p E 3$ and Xrp5, which have been demonstrated to be required for full virulence of $X$. oryzae pv. oryzicola (Cui et al. 2013; Xue et al. 2014). Meanwhile, we revealed that six putative effectors caused the HR in nonhost $N$. benthamiana plants through Agrobacterium-mediated transient gene expression.

Most of the mutations of individual non-TAL effector genes investigated here did not alter $X$. oryzae pv. oryzicola virulence, which is consistent with previous reports on plant bacterial pathogens. No non-TAL effectors but one TAL effector were identified to be required for $X$. oryzae pv. oryzicola virulence through a large-scale screening of a Tn5-tagged $X$. oryzae pv. oryzicola mutant library. In contrast, the study showed that many hrp genes are essential for its virulence (Guo et al. 2012). Virulence assays of the deletion mutants of 18 individual Xop genes in $X$. oryzae pv. oryzae revealed that XopZ is the only effector that is required for full virulence of $X$. oryzae $\mathrm{pv}$. oryzae in the susceptible host plant (Song and Yang 2010). Similarly, only the xopN mutation, out of seven effector genes tested in $X$. campestris pv. vesicatoria, has a detectable phenotypic effect on the pathogenicity (Roden et al. 2004). In addition, the mutants with disruption of eight $X$. campestris pv. campestris Xop genes individually or collectively did not exhibit any alteration in virulence compared with the wild-type strain on susceptible host plants (Castañeda et al. 2005). Experimental studies on other phytopathogenic bacteria also revealed that individual effector genes are often dispensable for pathogenesis of Pseudomonas syringae and Ralstonia solanacearum (Cunnac et al. 2004; Kvitko et al. 2009). Function redundancy of multiple effectors in one pathogenic organism is speculated to be a major factor that prevents detecting obvious phenotypic effect of individual effector mutations on host responses to pathogen infection. The hypothesis is supported by the findings that the same host targets have been identified for different sets of effectors in plant bacterial pathogens (Xin and He 2013). For instance, it was demonstrated that both of the effectors HopZ1a and HopX1 in $P$. syringae with different biochemical functions target to and promote degradation of JAZ proteins and contribute to bacterial virulence (Gimenez-Ibanez et al. 2014; Jiang et al. 2013). On the other hand, we cannot rule out another explanation. The effect on $X$. oryzae pv. oryzicola virulence of individual gene deletions might not be detected under experimental conditions used in this study. Some effectors have been shown to suppress preinvasive immunity, such as stomatal closure (Lozano-Durán et al. 2014). However, the pressure infiltration method used here for evaluating $X$. oryzae pv. oryzicola virulence most likely bypasses the first layer of rice immunity, such as stomatal defenses, which might be triggered before or during the natural entry of the pathogen into host extracellular spaces (Zeng et al. 2011).

Many effector proteins secreted by plant pathogens are known to have multiple activities, e.g., functioning as a virulence factor in the susceptible host plants, acting as an avirulence protein in the presence of its cognate resistance protein, or triggering $\mathrm{HR}$ in the nonhost plants (Göhre and Robatzek 2008). Here, we investigated the HR-eliciting activity of most of the $X$. oryzae pv. oryzicola putative effectors in the nonhost $N$. benthamiana plants using a heterogeneous expression system and revealed that at least six putative effectors, i.e., XopN, XopX, XopA, XopY, XopF1, and AvrBs2, caused the nonhost HR (Fig. 2). Among them, XopN, XopX, XopY, and AvrBs2 have been demonstrated to suppress plant immunity in other Xanthomonas species (Kim et al. 2009; Metz et al. 2005; Tai et al. 1999; Yamaguchi et al. 2013b). However, the functions of these effectors in $X$. oryzae pv. oryzicola virulence need to be further elucidated.

Interestingly, the $x о р A A$ deletion mutant was found to have an enhanced virulence to rice cv. Jingang 30, suggesting that XopAA secreted by $X$. oryzae pv. oryzicola induces immune responses in rice during infection (Fig. 1). A similar phenomenon has been reported for the $x \circ p Q$ mutant of $X$. oryzae pv. oryzicola, which exhibited an elevated virulence to rice cv. IR28 (Pei et al. 2010). We also demonstrated that the xopAA mutant was not more virulent than the wild-type strain to other rice cultivars. In addition, XopAA is relatively less conserved and is missing in X. campestris pv. campestris and $X$. campestris pv. citri as compared with core effectors in xanthomonads. Therefore, XopAA is less likely recognized as a conserved signature given that PAMPs and PTI signaling are usually highly conserved within species (Thomma et al. 2011). Presumably, XopAA is recognized as an avirulence protein and the R-Avr protein interaction is partially suppressed by virulence factors since no incompatible rice-X. oryzae pv. oryzicola interaction has been observed so far. Otherwise, XopAA might target negative regulators of rice defense signaling to initiate disease tolerance, which has been recently reported for XopD in X. campestris pv. campestris (Tan et al. 2014). Identification of one or more host targets of the effector XopAA will help to explain the phenomenon.

On the other hand, bacterial effector proteins often suppress PTI and, thereby, enhance pathogenesis in their host plants during the compatible interaction (Göhre and Robatzek 2008). Virulence assays revealed that $a v r B s 2$, among the 23 investigated effector genes, is the only one for which mutation caused a significant attenuation effect on $X$. oryzae pv. oryzicola virulence. The finding is interesting, since a previous mutagenesis study demonstrated that the mutation of $a v r B s 2$ did not significantly alter $X$. oryzae pv. oryzae virulence (Song and Yang 2010) and the avrBs 2 genes in $X$. oryzae pv. oryzae and $X$. oryzae pv. oryzicola share $97 \%$ coding sequence identity. Similarly, it was previously reported that the $r p f G$ mutants of $X$. campestris pv. campestris and $X$. oryzae pv. oryzicola have different virulence-associated phenotypes (Zhang et al. 2013). Distinct infection processes might cause different molecular mechanisms underlying virulence and pathogenicity among Xanthomonas species. In addition, genetic redundancy in the effector inventory of $X$. oryzae pv. oryzae and diverse genetic background of rice cultivars could also explain this phenomenon. It was reported that the same $X$. oryzae 
pv. oryzae strain might cause different phenotypes on different rice cultivars (Sinha et al. 2013). Subsequently, virulence functions of AvrBs2 were further confirmed using transient expression and transgenic technology. Ectopic expression of pathogen effectors in host plants has been widely used to elucidate virulence functions of bacterial and fungal effectors (Hauck et al. 2003; Park et al. 2012). NHO1 in Arabidopsis is essential for preventing the in planta growth of nonhost Pseudomonas bacteria (Lu et al. 2001). It is well known that flg22 induces the expression of $\mathrm{NHOl}$ ( $\mathrm{Li}$ et al. 2005). We demonstrated that AvrBs2 transiently expressed in Arabidopsis protoplasts suppressed flg22induced $\mathrm{NHO1}$ expression (Fig. 3A). Furthermore, induced expression of AvrBs2 in transgenic cell cultures was shown to dramatically suppress flg22-induced and chitin-induced immune responses, such as ROS burst and $P R$ gene expression (Fig. 4). Third, the AvrBs2-expressing transgenic rice plants displayed a nearly complete suppression of defense gene expression triggered by the PAMPs flg22 and chitin. Most importantly, heterologous expression of AvrBs2 in the transgenic plants facilitated bacterial colonization and multiplication in planta and accelerated disease progression (Fig. 5). The phenomenon that the AvrBs2expressing transgenic rice is more susceptible to $X$. oryzae pv. oryzicola than is the wild-type plant is likely due to the high expression level of AvrBs2 after DEX induction or expression timing of the effector before inoculation. A similar finding has been reported in avrPiz- $t$ transgenic rice plants that were more susceptible to fungal blast than was the wild-type plant (Park et al. 2012). In contrast, AvrBs 2 expression in the transgenic plants did not inhibit flg22- or chitin-triggered MAPK activation, suggesting that AvrBs2 blocks immune signaling transduction downstream of MAPK in rice or inhibits other branches of defense signaling independent of MAPK cascades. Taken together, our data indicate that AvrBs2 and the identified HrpE3 and Xrp5 effectors are essential virulence factors that contribute to full virulence of $X$. oryzae pv. oryzicola.

In summary, the study advanced our understanding of Xopmediated virulence in bacterial leaf streak. AvrBs2 has been demonstrated to be required for full virulence of $X$. campestris pv. vesicatoria on dicot plants, including pepper and tomato, through inhibition of host immunity (Zhao et al. 2011). Our results showed that AvrBs2 is also an essential virulence factor in $X$. oryzae pv. oryzicola, which suppresses immune responses in the monocot rice. These data suggest that AvrBs2 in $X$. campestris pv. vesicatoria and $X$. oryzae pv. oryzicola not only share high identity in protein sequence but, also, have a high function similarity. AvrBs2 might target defense signaling components shared by the dicot and monocot plants. Given the high structural and functional conservation of AvrBs2, it will be interesting to investigate whether the resistance gene $B s 2$ in pepper confers disease resistance across the dicot and monocot plant classes. The finding may provide insight into strategies to exploit alien disease resistance genes in rice breeding for broadspectrum and durable resistance to $X$. oryzae.

\section{MATERIALS AND METHODS}

Plant materials, bacterial strains, and culture conditions.

Oryza sativa L. subsp. japonica cvs. Jingang 30 and Nipponbare plants were grown in a greenhouse. Bacterial strains and plasmids used in this study are listed in Supplementary Table S2. A rifampicin-resistant $X$. oryzae pv. oryzicola RS105 was used as the wild type. The $X$. oryzae pv. oryzicola strains were grown in $\mathrm{NB}$ medium (per liter, $3 \mathrm{~g}$ of beef extract, $1 \mathrm{~g}$ of yeast extract, $5 \mathrm{~g}$ of tryptone, $10 \mathrm{~g}$ of sucrose) at $28^{\circ} \mathrm{C}$. Antibiotics were used at the following concentrations (micrograms per milliliter): ampicillin, 100; kanamycin, 50; and rifampin, 25. All the experiments were repeated at least three times with similar results, unless noted.
Construction of marker-free gene-deletion mutants in $X$. oryzae pv. oryzicola through homologous recombination.

The predicted effector genes in $X$. oryzae pv. oryzicola and genome sequences were available from the Xanthomonas Resource and the National Center for Biotechnology Information databases (Bogdanove et al. 2011). Construction of genedeletion mutant strains of $X$. oryzae pv. oryzicola was performed as described previously (Zhang et al. 2013). Briefly, genomic DNA was isolated from the X. oryzae pv. oryzicola wild-type strain RS105 using a genomic DNA isolation kit (New Industry Company, Beijing) according to the manufacturer's instructions. Two DNA fragments (approximately $1 \mathrm{~kb})$ upstream and downstream close to the start and stop codons of each effector gene, respectively, were amplified from the $X$. oryzae pv. oryzicola genome, using the primer sets listed in Supplementary Table S3. PCR products were gel-purified and were added together into a fusion PCR reaction to amplify DNA fragment carrying upstream and downstream regions of each effector gene but lacking the open reading frame (ORF). The resultant PCR products were cloned into pUFR80 that carries a $s a c B$ gene as the counter-selective marker (Castañeda et al. 2005; Ried and Collmer 1987). The constructed plasmids were conjugated into X. oryzae pv. oryzicola RS105 by triparental mating. The conjugants were selected on nutrient agar (NA) solid medium plates with kanamycin selection. After culturing in NB medium without sucrose, the conjugants were plated onto sucrose (5\%)-containing NA plates to screen sucrose-insensitive colonies. The gene-deletion genotypes of sucrose-insensitive $X$. oryzae pv. oryzicola colonies were selected using colony PCR. The mutants were subsequently subject to confirmation via Southern blot analyses.

\section{Construction of complementation strains}

for $X$. oryzae pv. oryzicola gene-deletion mutants.

For complementation, the full-length effector genes containing upstream promoter regions (approximately $800 \mathrm{bp}$ to approximately $1 \mathrm{~kb}$ ) were amplified by PCR, using genespecific primer sets. The amplified products were subcloned into the wide host-range vector pVSP61 (Loper and Lindow 1987). After being confirmed by sequencing, the plasmid constructs were transferred into the respective $X$. oryzae pv. oryzicola mutant strains by triparental conjugation. Single conjugants of $X$. oryzae pv. oryzicola were selected on the kanamycin-containing NA plates.

\section{Southern blot analysis.}

Southern blot analysis was performed as described previously (Cannon et al. 1979). Briefly, genomic DNA was isolated from the wild-type and mutant $X$. oryzae pv. oryzicola strains as described above and was then digested with appropriate restriction enzymes overnight. After separation on agarose gel, digested DNA was blotted onto Hybond-N nylon membrane (GE Healthcare, Buckinghamshire, U.K.). The probes were PCR-amplified and isotope $\left({ }^{32} \mathrm{P}\right)$-labeled using the Random Primer DNA labeling kit (Takara, Dalian, China).

\section{Transient expression of the effector proteins in $N$. benthamiana.}

The coding sequence of each putative effector gene of $X$. oryzae pv. oryzicola without the stop codon was amplified and cloned into the vector pUC19-35S-FLAG-RBS (Li et al. 2005), after digestion with XhoI and NarI for $a v r B s 2, X h o I$ and Csp45I for other effector genes, except хорAA, хорAB, хорO, and $x o p Z 1$. The four effector genes were not constructed for transient expression because no suitable restriction sites are available for these genes. The ORF of each effector gene with $3 \times$ FLAG coding sequence was cleaved from the corresponding 
pUC19-35S-FLAG-RBS construct with XhoI and SpeI and was religated into the DEX-inducible expression vector pTA7001 (Aoyama and Chua 1997). These constructed plasmids were transformed into the Agrobacterium sp. strain C58C1 through the freeze-thaw method (Deblaere et al. 1985). Overnightcultured Agrobacterium strains were collected and resuspended in $10 \mathrm{mM} \mathrm{MgCl}_{2}$ with $150 \mu \mathrm{M}$ acetosyringone (optical density at $600 \mathrm{~nm}\left[\mathrm{OD}_{600}\right]$, approximately 0.3 ). After incubation for $2 \mathrm{~h}$ or more, Agrobacterium cultures were infiltrated into the leaves of 6-week-old $N$. benthamiana plants with needleless syringes. These leaves were sprayed with $30 \mu \mathrm{M}$ DEX at $24 \mathrm{~h}$ after infiltration. The cell-death phenotypes on the leaves were observed and photographed at 3 days after DEX spraying.

\section{Subcellular localization and protoplast transfection assay.}

For subcellular localization, the coding sequence of GFP was amplified from pGWB5 (Nakagawa et al. 2007) and was ligated into the pUC19 plasmid after digestion with SphI and HindIII. The 35S promoter fragment was cleaved from pUC19-35SFLAG-RBS by EcoRI and $S a c I$ and was then religated into pUC19-GFP. The ORF of $a v r B s 2$ was amplified using the primer set avrBs2-BamHI-F and avrBs2-SalI-R and was then cloned into pUC19-35S-GFP after digestion with BamHI and SalI. The construct was confirmed by sequencing.

The transfection assay in protoplasts was carried out as described previously ( $\mathrm{Li}$ et al. 2005). Briefly, protoplasts were isolated from 10-day-old etiolated seedlings of Oryza sativa cv. Nipponbare or the leaves of 4-week-old NHO1-LUC transgenic Arabidopsis plants. The protoplasts (approximately $2.5 \times 10^{6}$ protoplasts per milliliter) were transfected with $10 \mu \mathrm{g}$ of plasmid DNA by polyethylene glycol-mediated transformation. After washing with W5 solution $(154 \mathrm{mM} \mathrm{NaCl}, 125 \mathrm{mM}$ $\mathrm{CaCl}_{2}, 5 \mathrm{mM} \mathrm{KCl}$, and $2 \mathrm{mM}$ MES-KOH, $\mathrm{pH}$ 5.7), the protoplasts were resuspended in W5 solution and were treated with $1 \mu \mathrm{M}$ flg 22 for $12 \mathrm{~h}$, under low light. The LUC activity was then evaluated by measuring luminescence intensity $10 \mathrm{~min}$ after adding $50 \mu \mathrm{M}$ luciferin to the transfected Arabidopsis protoplasts. GFP fluorescence on the transfected rice protoplasts was observed using confocal microscopy (Nikon Ti2000).

\section{Development of the avrBs 2 transgenic plants and cell cultures.}

The pTA7001-avrBs 2 construct was introduced into rice calli through Agrobacterium-mediated transformation as described previously (Ozawa 2009). Briefly, the sterilized dehusked seeds (cv. Nipponbare) were plated onto NBi medium (N6 macro elements, B5 microelements, B5 vitamin, $27.8 \mathrm{mg}$ of $\mathrm{FeSO}_{4} \cdot 7 \mathrm{H}_{2} \mathrm{O}$ per liter, $37.3 \mathrm{mg}$ of Na2-EDTA per liter, $500 \mathrm{mg}$ of proline per liter, and $500 \mathrm{mg}$ of glutamine per liter, $300 \mathrm{mg}$ of casein hydrolysate per liter, $2 \mathrm{mg}$ of 2,4-dichlorophenoxyacetic acid $(2,4-\mathrm{D})$ per liter, $100 \mathrm{mg}$ of inositol per liter, and $30 \mathrm{~g}$ sucrose per liter) for callus induction. The vigorous calli were picked and incubated with Agrobacterium cultures for $2 \mathrm{~min}$ and were then transferred onto NBco medium (NBi medium supplied with $100 \mu \mathrm{M}$ acetosyringone, $\mathrm{pH}$ 5.5) for 3 days. The calli were subsequently cultured onto NBs medium (NBi medium supplied with $500 \mathrm{mg}$ of cephamycin and $30 \mathrm{mg}$ of hygromycin per liter), after washing thoroughly with sterile water. The resistant calli that emerged after approximately 3 to 4 weeks were transferred onto $\mathrm{NBr}$ medium (NBi medium supplied with, per liter, $0.5 \mathrm{mg}$ of $\alpha$-naphthalene acetic acid, $3 \mathrm{mg}$ of 6benzylaminopurine, $500 \mathrm{mg}$ of cephamycin, and $30 \mathrm{mg}$ of hygromycin) for shooting. The regenerated shoots were transferred onto $1 / 2 \times$ Murashige and Skoog medium containing $100 \mathrm{mg}$ of inositol per liter for rooting. The independent transgenic plants were transferred to the greenhouse for further growth.
Rice cell-suspension cultures were initiated from the wildtype and avrBs 2 transgenic calli as described previously (Ozawa and Komamine 1989). Briefly, the compact calli with vigorous growth were inoculated in $100 \mathrm{ml}$ of liquid N6 medium supplemented with $5 \mathrm{mg}$ of 2,4-D and $1 \mathrm{mg}$ of kinetin per liter, to establish cell suspension cultures. Hygromycin (30 mg/liter) was added for culturing the $a v r B s 2$ transgenic calli. The suspension cultures were incubated at $26^{\circ} \mathrm{C}$ on a rotary shaker at $140 \mathrm{rpm}$.

\section{Oxidative burst assays.}

ROS burst in rice cell cultures was detected as described previously with minor modifications (Lu et al. 2015; Pérez and Rubio 2006). Briefly, equal volumes of calli were incubated in fresh culture medium for $24 \mathrm{~h}$ at $26^{\circ} \mathrm{C}$. DEX was then added into cell cultures to the final concentration of $10 \mu \mathrm{M}$ to induce AvrBs2 expression. Ethanol $(0.03 \%)$ was added into cultured cells as mock control. After incubation for another $24 \mathrm{~h}$, cultured cells were washed three times and were then incubated in $3 \mathrm{ml}$ of fresh media in a $20-\mathrm{ml}$ vial for $3 \mathrm{~h}$ at $26^{\circ} \mathrm{C}$. The cells were then treated with $1 \mu \mathrm{M}$ flg 22 or $20 \mu \mathrm{l}$ of $100 \mathrm{mg}$ of chitin per milliliter. The supernatant $(10 \mu \mathrm{l})$ was collected at different time points after treatments and was mixed with $1 \mathrm{ml}$ of $\mathrm{Co}(\mathrm{II})-$ luminol reagent. Chemiluminescence was recorded immediately by the Infinite F200 (Tecan, Grödig, Salzburg, Austria) with the count time set as $1 \mathrm{~s}$.

\section{Protein extraction and immunoblotting.}

The avrBs 2 transgenic calli treated with DEX or mock $(0.03 \%$ ethanol) were collected and were ground in the centrifuge tubes with small stainless steel balls, using a milling apparatus (Retsch, Haan, Germany) for total protein extraction. The sample loading buffer $(50 \mathrm{mM}$ Tris- $\mathrm{HCl}, \mathrm{pH} 6.8,2 \%$ sodium dodecyl sulfate, $6 \%$ glycerol, $0.1 \mathrm{M}$ dithiothreitol, $0.01 \%$ bromophenol blue) was added directly into the tubes. The samples were boiled for $20 \mathrm{~min}$, and the supernatants were collected for gel separation. For detecting transient expression of the effectors in $N$. benthamiana, total proteins were extracted from the ground powder of infiltrated leaves, using the extraction buffer $(50 \mathrm{mM}$ Tris- $\mathrm{HCl}, \mathrm{pH} 7.4,150 \mathrm{mM} \mathrm{NaCl}, 1 \mathrm{mM}$ EDTA, $1 \%$ Triton $\mathrm{X}-100,1 \%$ protease inhibitor cocktail [Merck, San Diego, CA, U.S.A.]).

The extracted proteins were separated in a $12 \%$ polyacrylamide gel and were electrophoretically transferred onto Immobilon-P membrane (Millipore, Bedford, MA, U.S.A.) as described previously (Sun et al. 2012). Nonspecific binding sites on the membranes were blocked overnight in blocking solution consisting of $5 \%(\mathrm{wt} / \mathrm{vol})$ skimmed milk in TBS-T (10 mM Tris-HCl, pH 8.0, $150 \mathrm{mM} \mathrm{NaCl}$, and $0.05 \%$ Tween 20) at $4^{\circ} \mathrm{C}$. The membranes were then incubated with an anti-FLAG monoclonal antibody (Sigma, St. Louis) at a dilution of 1:5,000 in blocking solution for $1 \mathrm{~h}$ at room temperature. Following three 10-min washes in TBS-T, the membranes were incubated for $1 \mathrm{~h}$ at room temperature in TBS-T containing horseradish peroxidase (HRP)-conjugated goat antimouse immunoglobulin $\mathrm{G}$ (IgG) secondary antibody (1:5,000 dilution) (CWBio, Beijing). After three washes in TBS-T, the membranes were incubated with the eECL Western Blot chemiluminescent substrate (CWBio) for 5 min and were then exposed to X-ray films. MAPK activation was detected as described (Schwessinger et al. 2011). Briefly, the immunoblots were blocked in 5\% (wt/vol) bovine serum albumin (MP Biomedicals, Santa Ana, CA, U.S.A.) in TBS-T for $1 \mathrm{~h}$ at $4^{\circ} \mathrm{C}$. Phospho-serine and threonine sites were detected using anti-Phospho-p44/42 MAPK antibody (1:2,000 dilution) (Cell Signaling Technology, Danvers, MA, U.S.A.), followed by HRPconjugated antirabbit IgG secondary antibody (CWBio) at a dilution of $1: 5,000$. 
RNA isolation and quantitative real-time RT-PCR.

The transgenic plant leaves and cell cultures were treated with flg 22 and chitin for $6 \mathrm{~h}$ after treatment with DEX to induce AvrBs2 expression. Total RNA was isolated from the treated avrBs 2 transgenic plants and cells using an Ultrapure RNA isolation kit, according to the manufacturer's instructions (CWBio). Complementary DNA (cDNA) was synthesized by reverse transcription Superscript III (Invitrogen, Carlsbad, CA, U.S.A.) using total RNA as template. The transcript levels of defense genes were quantified through quantitative real time RT-PCR with SYBR premix Ex Taq (Takara) using an ABI PRISM 7000 Sequence Detection System (Applied Biosystems, Foster City, CA, U.S.A.). The expression level of OsActin1 (Os03g0718100) was used as an internal reference.

\section{Virulence assays of $X$. oryzae pv. oryzicola and $X$. oryzae pv. oryzae on rice.}

Virulence of different $X$. oryzae pv. oryzicola gene-deletion mutant strains was determined on rice cv. Jingang 30 by pressure inoculation (Wang et al. 2007). The avrBs2 transgenic plants were sprayed with $30 \mu \mathrm{M}$ DEX or $0.1 \%$ ethanol as mock control 1 day before bacterial inoculation. For bacterial leaf streak, $X$. oryzae pv. oryzicola strains were cultured in NB medium overnight and were diluted with sterile double-distilled water to an $\mathrm{OD}_{600}$ of 0.3 and were then pressure-infiltrated into 6-week-old rice leaves with needleless syringes. For rice bacterial blight, the $X$. oryzae pv. oryzae PXO99A $\left(\mathrm{OD}_{600}\right.$, approximately 0.8 ) was inoculated into rice leaves by the leafclipping method (Kauffman et al. 1973). Disease lesions on the inoculated leaves were measured at 14 days after inoculation. At least 10 inoculated leaves were scored for each tested strain.

For establishing bacterial growth curves, leaf sections around inoculation sites were harvested at four time points $(0,4,8$, and 12 days after inoculation) and sliced into small pieces, were incubated in $5 \mathrm{ml}$ of sterile water including rifampicin $(25 \mu \mathrm{g} / \mathrm{ml})$ with shaking for $1 \mathrm{~h}$, and then, were filtered through two layers of sterilization gauze. The filtrates were diluted and were then plated onto NA plates with rifampicin. Colonies on the plates were counted after 3 days of incubation at $28^{\circ} \mathrm{C}$.

\section{ACKNOWLEDGMENTS}

We thank J. Zhou at the Institute of Genetics and Developmental Biology of the Chinese Academy of Sciences for providing the pUC19-35S-FLAGRBS plasmid vector and NHO1-LUC transgenic Arabidopsis plants. The work is supported by the National High Technology Research and Development program of China 2012AA100703, the Transgenic Crop Project 2012ZX08009003-003, the 973 Program 2011CB100700, the National Natural Science Foundation of China (NSFC) grant 31272007 and the 111 Project B13006 to W. Sun.

\section{LITERATURE CITED}

Akimoto-Tomiyama, C., Furutani, A., Tsuge, S., Washington, E. J., Nishizawa, Y., Minami, E., and Ochiai, H. 2012. XopR, a type III effector secreted by Xanthomonas oryzae pv. oryzae, suppresses microbe-associated molecular pattern-triggered immunity in Arabidopsis thaliana. Mol. Plant-Microbe Interact. 25:505-514.

Alfano, J. R., and Collmer, A. 2004. Type III secretion system effector proteins: Double agents in bacterial disease and plant defense. Annu. Rev. Phytopathol. 42:385-414.

Aoyama, T., and Chua, N. H. 1997. A glucocorticoid-mediated transcriptional induction system in transgenic plants. Plant J. 11:605-612.

Boch, J., and Bonas, U. 2010. Xanthomonas AvrBs3 family-type III effectors: Discovery and function. Annu. Rev. Phytopathol. 48:419-436.

Bogdanove, A. J., Koebnik, R., Lu, H., Furutani, A., Angiuoli, S. V., Patil, P. B., Van Sluys, M. A., Ryan, R. P., Meyer, D. F., Han, S. W., Aparna, G., Rajaram, M., Delcher, A. L., Phillippy, A. M., Puiu, D., Schatz, M. C., Shumway, M., Sommer, D. D., Trapnell, C., Benahmed, F., Dimitrov, G., Madupu, R., Radune, D., Sullivan, S., Jha, G., Ishihara, H.,
Lee, S. W., Pandey, A., Sharma, V., Sriariyanun, M., Szurek, B., Vera-Cruz, C. M., Dorman, K. S., Ronald, P. C., Verdier, V., Dow, J. M., Sonti, R. V., Tsuge, S., Brendel, V. P., Rabinowicz, P. D., Leach, J. E., White, F. F., and Salzberg, S. L. 2011. Two new complete genome sequences offer insight into host and tissue specificity of plant pathogenic Xanthomonas spp. J. Bacteriol. 193:5450-5464.

Boller, T., and He, S. Y. 2009. Innate immunity in plants: An arms race between pattern recognition receptors in plants and effectors in microbial pathogens. Science 324:742-744.

Cannon, F. C., Riedel, G. E., and Ausubel, F. M. 1979. Overlapping sequences of Klebsiella pneumoniae nifDNA cloned and characterized. Mol. Gen. Genet. 174:59-66.

Castañeda, A., Reddy, J. D., El-Yacoubi, B., and Gabriel, D. W. 2005. Mutagenesis of all eight avr genes in Xanthomonas campestris pv. campestris had no detected effect on pathogenicity, but one avr gene affected race specificity. Mol. Plant-Microbe Interact. 18:1306-1317.

Cheong, H., Kim, C. Y., Jeon, J. S., Lee, B. M., Sun Moon, J., and Hwang, I. 2013. Xanthomonas oryzae pv. oryzae type III effector XopN targets OsVOZ2 and a putative thiamine synthase as a virulence factor in rice. PLoS ONE 8:e73346.

Chisholm, S. T., Coaker, G., Day, B., and Staskawicz, B. J. 2006. Hostmicrobe interactions: Shaping the evolution of the plant immune response. Cell 124:803-814.

Cui, Y., Zou, L., Zou, H., Li, Y., Zakria, M., and Chen, G. 2013. HrpE3 is a type III effector protein required for full virulence of Xanthomonas oryzae pv. oryzicola in rice. Mol. Plant Pathol. 14:678-692.

Cunnac, S., Occhialini, A., Barberis, P., Boucher, C., and Genin, S. 2004. Inventory and functional analysis of the large Hrp regulon in Ralstonia solanacearum: Identification of novel effector proteins translocated to plant host cells through the type III secretion system. Mol. Microbiol. 53: 115-128.

Deblaere, R., Bytebier, B., De Greve, H., Deboeck, F., Schell, J., Van Montagu, M., and Leemans, J. 1985. Efficient octopine Ti plasmidderived vectors for Agrobacterium-mediated gene transfer to plants. Nucleic Acids Res. 13:4777-4788.

Dou, D., and Zhou, J. M. 2012. Phytopathogen effectors subverting host immunity: Different foes, similar battleground. Cell Host Microbe 12: 484-495.

Feng, F., Yang, F., Rong, W., Wu, X., Zhang, J., Chen, S., He, C., and Zhou, J. M. 2012. A Xanthomonas uridine 5'-monophosphate transferase inhibits plant immune kinases. Nature 485:114-118.

Furutani, A., Nakayama, T., Ochiai, H., Kaku, H., Kubo, Y., and Tsuge, S. 2006. Identification of novel HrpXo regulons preceded by two cis-acting elements, a plant-inducible promoter box and a -10 box-like sequence, from the genome database of Xanthomonas oryzae pv. oryzae. FEMS (Fed. Eur. Microbiol. Soc.). Lett. 259:133-141.

Furutani, A., Takaoka, M., Sanada, H., Noguchi, Y., Oku, T., Tsuno, K., Ochiai, H., and Tsuge, S. 2009. Identification of novel type III secretion effectors in Xanthomonas oryzae pv. oryzae. Mol. Plant-Microbe Interact. 22:96-106.

Gassmann, W., Dahlbeck, D., Chesnokova, O., Minsavage, G. V., Jones, J. B., and Staskawicz, B. J. 2000. Molecular evolution of virulence in natural field strains of Xanthomonas campestris pv. vesicatoria. J. Bacteriol. 182:7053-7059.

Gimenez-Ibanez, S., Boter, M., Fernández-Barbero, G., Chini, A., Rathjen, J. P., and Solano, R. 2014. The bacterial effector HopX1 targets JAZ transcriptional repressors to activate jasmonate signaling and promote infection in Arabidopsis. PLoS Biol. 12:e1001792.

Göhre, V., and Robatzek, S. 2008. Breaking the barriers: Microbial effector molecules subvert plant immunity. Annu. Rev. Phytopathol. 46:189-215.

Guo, W., Cui, Y. P., Li, Y. R., Che, Y. Z., Yuan, L., Zou, L. F., Zou, H. S., and Chen, G. Y. 2012. Identification of seven Xanthomonas oryzae pv. oryzicola genes potentially involved in pathogenesis in rice. Microbiology 158:505-518.

Hauck, P., Thilmony, R., and He, S. Y. 2003. A Pseudomonas syringae type III effector suppresses cell wall-based extracellular defense in susceptible Arabidopsis plants. Proc. Natl. Acad. Sci. U.S.A. 100:8577-8582.

Jiang, S., Yao, J., Ma, K. W., Zhou, H., Song, J., He, S. Y., and Ma, W. 2013. Bacterial effector activates jasmonate signaling by directly targeting JAZ transcriptional repressors. PLoS Pathog. 9:e1003715.

Jones, J. D., and Dangl, J. L. 2006. The plant immune system. Nature 444: 323-329.

Kauffman, H. E., Reddy, A. P. K., and Hsieh, S. P. Y. 1973. An improved technique for evaluation of resistance of rice varieties to Xanthomonas oryzae. Plant Dis. 57:537-541.

Kay, S., and Bonas, U. 2009. How Xanthomonas type III effectors manipulate the host plant. Curr. Opin. Microbiol. 12:37-43. 
Kearney, B., and Staskawicz, B. J. 1990. Widespread distribution and fitness contribution of Xanthomonas campestris avirulence gene avrBs2. Nature 346:385-386.

Kim, J. G., Taylor, K. W., Hotson, A., Keegan, M., Schmelz, E. A., and Mudgett, M. B. 2008. XopD SUMO protease affects host transcription, promotes pathogen growth, and delays symptom development in Xanthomonas-infected tomato leaves. Plant Cell 20:1915-1929.

Kim, J. G., Li, X., Roden, J. A., Taylor, K. W., Aakre, C. D., Su, B. Lalonde, S., Kirik, A., Chen, Y., Baranage, G., McLane, H., Martin, G. B., and Mudgett, M. B. 2009. Xanthomonas T3S effector XopN suppresses PAMP-triggered immunity and interacts with a tomato atypical receptor-like kinase and TFT1. Plant Cell 21:1305-1323.

Kim, J. G., Stork, W., and Mudgett, M. B. 2013. Xanthomonas type III effector XopD desumoylates tomato transcription factor SIERF4 to suppress ethylene responses and promote pathogen growth. Cell Host Microbe 13:143-154.

Koebnik, R., Krüger, A., Thieme, F., Urban, A., and Bonas, U. 2006 Specific binding of the Xanthomonas campestris pv. vesicatoria AraCtype transcriptional activator $\mathrm{HrpX}$ to plant-inducible promoter boxes. J. Bacteriol. 188:7652-7660.

Kvitko, B. H., Park, D. H., Velásquez, A. C., Wei, C. F., Russell, A. B., Martin, G. B., Schneider, D. J., and Collmer, A. 2009. Deletions in the repertoire of Pseudomonas syringae pv. tomato DC3000 type III secretion effector genes reveal functional overlap among effectors. PLoS Pathog. 5:e1000388.

Li, X., Lin, H., Zhang, W., Zou, Y., Zhang, J., Tang, X., and Zhou, J. M. 2005. Flagellin induces innate immunity in nonhost interactions that is suppressed by Pseudomonas syringae effectors. Proc. Natl. Acad. Sci. U.S.A. 102:12990-12995.

Li, Y. R., Zou, H. S., Che, Y. Z., Cui, Y. P., Guo, W., Zou, L. F., Chatterjee, S., Biddle, E. M., Yang, C. H., and Chen, G. Y. 2011. A novel regulatory role of HrpD6 in regulating hrp-hrc-hpa genes in Xanthomonas oryzae pv. oryzicola. Mol. Plant-Microbe Interact. 24:1086-1101.

Li, W., Yadeta, K. A., Elmore, J. M., and Coaker, G. 2013. The Pseudomonas syringae effector HopQ1 promotes bacterial virulence and interacts with tomato 14-3-3 proteins in a phosphorylationdependent manner. Plant Physiol. 161:2062-2074.

Loper, J. E., and Lindow, S. E. 1987. Lack of evidence for the in situ fluorescent pigment production by Pseudomonas syringae pv. syringae on bean leaf surfaces. Phytopathology 77:1449-1454.

Lozano-Durán, R., Bourdais, G., He, S. Y., and Robatzek, S. 2014. The bacterial effector HopM1 suppresses PAMP-triggered oxidative burst and stomatal immunity. New Phytol. 202:259-269.

Lu, M., Tang, X., and Zhou, J. M. 2001. Arabidopsis NHO1 is required for general resistance against Pseudomonas bacteria. Plant Cell 13: 437-447.

Lu, F., Wang, H., Wang, S., Jiang, W., Shan, C., Li, B., Yang, J., Zhang, S., and Sun, W. 2015. Enhancement of innate immune system in monoco rice by transferring the dicotyledonous elongation factor $\mathrm{Tu}$ receptor EFR. J. Integr. Plant Biol. Published online.

Makino, S., Sugio, A., White, F., and Bogdanove, A. J. 2006. Inhibition of resistance gene-mediated defense in rice by Xanthomonas oryzae pv. oryzicola. Mol. Plant-Microbe Interact. 19:240-249.

Metz, M., Dahlbeck, D., Morales, C. Q., Al Sady, B., Clark, E. T., and Staskawicz, B. J. 2005. The conserved Xanthomonas campestris pv. vesicatoria effector protein $\mathrm{XopX}$ is a virulence factor and suppresses host defense in Nicotiana benthamiana. Plant J. 41:801-814.

Nakagawa, T., Kurose, T., Hino, T., Tanaka, K., Kawamukai, M., Niwa, Y., Toyooka, K., Matsuoka, K., Jinbo, T., and Kimura, T. 2007. Development of series of gateway binary vectors, pGWBs, for realizing efficient construction of fusion genes for plant transformation. J. Biosci. Bioeng. 104:34-41.

Niño-Liu, D. O., Ronald, P. C., and Bogdanove, A. J. 2006. Xanthomonas oryzae pathovars: Model pathogens of a model crop. Mol. Plant Pathol. 7:303-324.

Ozawa, K. 2009. Establishment of a high efficiency Agrobacteriummediated transformation system of rice (Oryza sativa L.). Plant Sci. 176: 522-527.

Ozawa, K., and Komamine, A. 1989. Establishment of a system of highfrequency embryogenesis from long-term cell suspension cultures of rice (Oryza sativa L.). Theor. Appl. Genet. 77:205-211.

Park, C. H., Chen, S., Shirsekar, G., Zhou, B., Khang, C. H., Songkumarn, P., Afzal, A. J., Ning, Y., Wang, R., Bellizzi, M., Valent, B., and Wang, G. L. 2012. The Magnaporthe oryzae effector AvrPiz-t targets the RING E3 ubiquitin ligase APIP6 to suppress pathogen-associated molecular pattern-triggered immunity in rice. Plant Cell 24:4748-4762.

Pei, J. G., Zou, L. F., Zou, H. S., and Chen, G. Y. 2010. Functional analysis of $x o p Q 1_{\text {Xос }}$ gene from Xanthomonas oryzae pv. oryzicola in pathogenesis on rice. Sci. Agric. Sin. 17:3538-3546
Pereira, A. L., Carazzolle, M. F., Abe, V. Y., de Oliveira, M. L., Domingues, M. N., Silva, J. C., Cernadas, R. A., and Benedetti, C. E. 2014. Identification of putative TAL effector targets of the citrus canker pathogens shows functional convergence underlying disease development and defense response. BMC Genomics 15:157.

Pérez, F. J., and Rubio, S. 2006. An improved chemiluminescence method for hydrogen peroxide determination in plant tissues. Plant Growth Regul. 48:89-95.

Ried, J. L., and Collmer, A. 1987. An nptI-sacB-sacR cartridge for constructing directed, unmarked mutations in gram-negative bacteria by marker exchange-eviction mutagenesis. Gene 57:239-246.

Roden, J. A., Belt, B., Ross, J. B., Tachibana, T., Vargas, J., and Mudgett, M. B. 2004. A genetic screen to isolate type III effectors translocated into pepper cells during Xanthomonas infection. Proc. Natl. Acad. Sci U.S.A. 101:16624-16629.

Rosebrock, T. R., Zeng, L., Brady, J. J., Abramovitch, R. B., Xiao, F., and Martin, G. B. 2007. A bacterial E3 ubiquitin ligase targets a host protein kinase to disrupt plant immunity. Nature 448:370-374.

Scholze, H., and Boch, J. 2011. TAL effectors are remote controls for gene activation. Curr. Opin. Microbiol. 14:47-53.

Schwessinger, B., Roux, M., Kadota, Y., Ntoukakis, V., Sklenar, J., Jones, A., and Zipfel, C. 2011. Phosphorylation-dependent differential regulation of plant growth, cell death, and innate immunity by the regulatory receptor-like kinase BAK1. PLoS Genet. 7:e1002046.

Shimizu, T., Nakano, T., Takamizawa, D., Desaki, Y., Ishii-Minami, N., Nishizawa, Y., Minami, E., Okada, K., Yamane, H., Kaku, H., and Shibuya, N. 2010. Two LysM receptor molecules, CEBiP and OsCERK1, cooperatively regulate chitin elicitor signaling in rice. Plant J. 64:204-214

Sinha, D., Gupta, M. K., Patel, H. K., Ranjan, A., and Sonti, R. V. 2013. Cell wall degrading enzyme induced rice innate immune responses are suppressed by the type 3 secretion system effectors XopN, XopQ, XopX and XopZ of Xanthomonas oryzae pv. oryzae. PLoS ONE 8:e75867.

Song, C., and Yang, B. 2010. Mutagenesis of 18 type III effectors reveals virulence function of XopZ( (pXo99 ) in Xanthomonas oryzae pv. oryzae. Mol. Plant-Microbe Interact. 23:893-902.

Sun, W., Cao, Y., Jansen Labby, K., Bittel, P., Boller, T., and Bent, A. F. 2012. Probing the Arabidopsis flagellin receptor: FLS2-FLS2 association and the contributions of specific domains to signaling function Plant Cell 24:1096-1113.

Swords, K. M., Dahlbeck, D., Kearney, B., Roy, M., and Staskawicz, B. J. 1996. Spontaneous and induced mutations in a single open reading frame alter both virulence and avirulence in Xanthomonas campestris pv. vesicatoria avrBs2. J. Bacteriol. 178:4661-4669.

Tai, T. H., Dahlbeck, D., Clark, E. T., Gajiwala, P., Pasion, R., Whalen, M. C., Stall, R. E., and Staskawicz, B. J. 1999. Expression of the Bs2 pepper gene confers resistance to bacterial spot disease in tomato. Proc. Natl. Acad. Sci. U.S.A. 96:14153-14158.

Takai, R., Isogai, A., Takayama, S., and Che, F. S. 2008. Analysis of flagellin perception mediated by flg22 receptor OsFLS2 in rice. Mol. Plant-Microbe Interact. 21:1635-1642.

Tampakaki, A. P., Fadouloglou, V. E., Gazi, A. D., Panopoulos, N. J., and Kokkinidis, M. 2004. Conserved features of type III secretion. Cell. Microbiol. 6:805-816.

Tan, L., Rong, W., Luo, H., Chen, Y., and He, C. 2014. The Xanthomonas campestris effector protein $\mathrm{XopD}_{X c c 8004}$ triggers plant disease tolerance by targeting DELLA proteins. New Phytol. 204:595-608.

Teper, D., Salomon, D., Sunitha, S., Kim, J. G., Mudgett, M. B., and Sessa, G. 2014. Xanthomonas euvesicatoria type III effector XopQ interacts with tomato and pepper 14-3-3 isoforms to suppress effector-triggered immunity. Plant J. 77:297-309.

Thomma, B. P., Nürnberger, T., and Joosten, M. H. 2011. Of PAMPs and effectors: The blurred PTI-ETI dichotomy. Plant Cell 23:4-15.

Tsuge, S., Nakayama, T., Terashima, S., Ochiai, H., Furutani, A., Oku, T. Tsuno, K., Kubo, Y., and Kaku, H. 2006. Gene involved in transcriptional activation of the hrp regulatory gene hrpG in Xanthomonas oryzae pv. oryzae. J. Bacteriol. 188:4158-4162.

Underwood, W., Zhang, S., and He, S. Y. 2007. The Pseudomonas syringae type III effector tyrosine phosphatase HopAO1 suppresses innate immunity in Arabidopsis thaliana. Plant J. 52:658-672.

Üstün, S., Bartetzko, V., and Börnke, F. 2013. The Xanthomonas campestris type III effector XopJ targets the host cell proteasome to suppress salicylic-acid mediated plant defence. PLoS Pathog. 9:e1003427.

Vauterin, L., Hoste, B., Kersters, K., and Swings, J. 1995. Reclassification of Xanthomonas. Int. J. Syst. Bacteriol. 45:472-489.

Wang, L., Makino, S., Subedee, A., and Bogdanove, A. J. 2007. Novel candidate virulence factors in rice pathogen Xanthomonas oryzae pv. oryzicola as revealed by mutational analysis. Appl. Environ. Microbiol. 73: 8023-8027. 
White, F. F., Potnis, N., Jones, J. B., and Koebnik, R. 2009. The type III effectors of Xanthomonas. Mol. Plant Pathol. 10:749-766.

Xin, X. F., and He, S. Y. 2013. Pseudomonas syringae pv. tomato DC3000: A model pathogen for probing disease susceptibility and hormone signaling in plants. Annu. Rev. Phytopathol. 51: 473-498.

Xue, X. B., Zou, L. F., Ma, W. X., Liu, Z. Y., and Chen, G. Y. 2014. Identification of $17 \mathrm{HrpX}$-regulated proteins including two novel type III effectors, XOC_3956 and XOC_1550, in Xanthomonas oryzae pv. oryzicola. PLoS ONE 9:e93205.

Yamaguchi, K., Nakamura, Y., Ishikawa, K., Yoshimura, Y., Tsuge, S., and Kawasaki, T. 2013a. Suppression of rice immunity by Xanthomonas oryzae type III effector Xoo2875. Biosci. Biotechnol. Biochem. 77: 796-801.

Yamaguchi, K., Yamada, K., Ishikawa, K., Yoshimura, S., Hayashi, N., Uchihashi, K., Ishihama, N., Kishi-Kaboshi, M., Takahashi, A., Tsuge, S., Ochiai, H., Tada, Y., Shimamoto, K., Yoshioka, H., and Kawasaki, T. 2013b. A receptor-like cytoplasmic kinase targeted by a plant pathogen effector is directly phosphorylated by the chitin receptor and mediates rice immunity. Cell Host Microbe 13:347-357.

Zeng, W., Brutus, A., Kremer, J. M., Withers, J. C., Gao, X., Jones, A. D., and He, S. Y. 2011. A genetic screen reveals Arabidopsis stomatal and/or apoplastic defenses against Pseudomonas syringae pv. tomato DC3000. PLoS Pathog. 7:e1002291.

Zhang, Y., Wei, C., Jiang, W., Wang, L., Li, C., Wang, Y., Dow, J. M., and Sun, W. 2013. The HD-GYP domain protein RpfG of Xanthomonas oryzae pv. oryzicola regulates synthesis of extracellular polysaccharides that contribute to biofilm formation and virulence on rice. PLoS ONE 8:e59428.

Zhao, B., Ardales, E. Y., Raymundo, A., Bai, J., Trick, H. N., Leach, J. E., and Hulbert, S. H. 2004. The avrRxol gene from the rice pathogen Xanthomonas oryzae pv. oryzicola confers a nonhost defense reaction on maize with resistance gene Rxol. Mol. Plant-Microbe Interact. 17: 771-779.

Zhao, B., Dahlbeck, D., Krasileva, K. V., Fong, R. W., and Staskawicz, B. J. 2011. Computational and biochemical analysis of the Xanthomonas effector AvrBs2 and its role in the modulation of Xanthomonas type three effector delivery. PLoS Pathog. 7: e1002408.

\section{AUTHOR-RECOMMENDED INTERNET RESOURCES}

The National Center for Biotechnology Information database: http://www.ncbi.nlm.nih.gov

The Xanthomonas Resource database: http://www.xanthomonas.org 